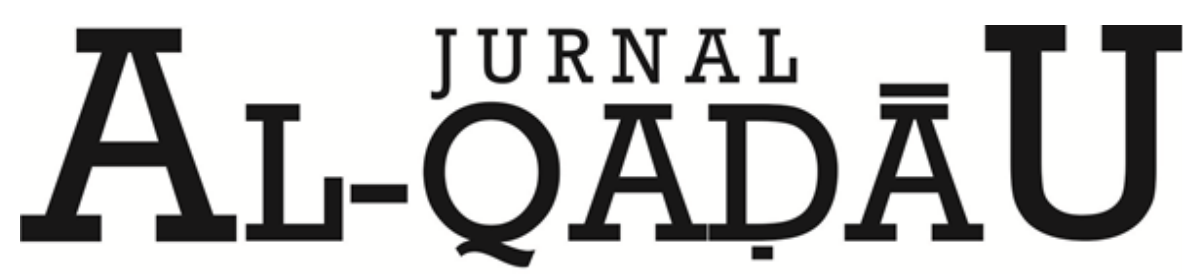

PERADILAN dan HUKUM KELUARGA ISLAM

\title{
Karakteristik dan Aspek Hukum dalam Kewirausahaan
}

Characteristics and Legal Aspects of Entrepreneurship

Wahida Rahim

Fakultas Syariah dan Hukum UIN Alauddin Makassar

Email: wahidarahim48@gmail.com

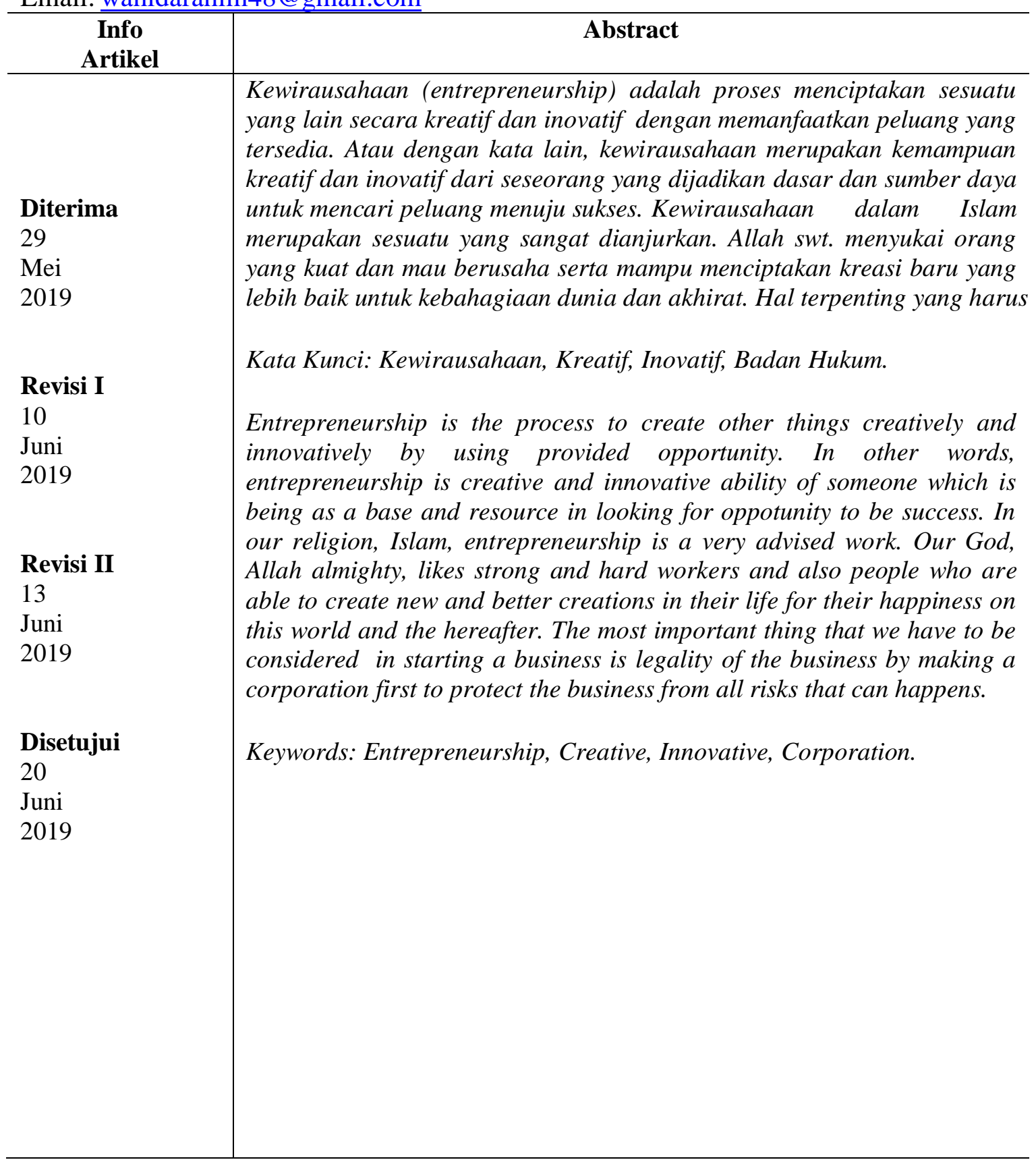




\section{A. PENDAHULUAN}

Kewirausahaan atau yang lebih familiar dikenal dengan istilah entrepreneurship merupakan kemampuan untuk mengembangkan ide dan cara yang kreatif dan inovatif yang dijadikan dasar, kiat, dan sumber daya untuk mendeteksi dan menemukan peluang yang kemudian dapat diterapkannya hal-hal tersebut untuk menuju kesuksesan.

Kewirausahaan adalah proses dinamik untuk menciptakan tambahan kemakmuran. Tambahan kemakmuran ini diciptakan oleh individu wirausaha yang berani menanggung risiko, menghabiskan waktu, dan menyediakan berbagai produk dan jasa. Barang dan jasa yang dihasilkan boleh saja saja bukan merupakan barang baru tetapi mesti mempunyai nilai yang baru dan berguna dengan memanfaatkan skill dan sumber daya yang ada. Dari segi karakteristik perilaku, wirausaha adalah mereka yang mendirikan, mengelola, mengembangkan, dan melembagakan perusahaan miliknya sendiri dan yang bisa menciptakan kerja bagi orang lain. Hal ini mengandung asumsi bahwa setiap orang yang mempunyai kemampuan normal dapat menjadi wirausaha dengan syarat mau dan mempunyai kesempatan untuk belajar dan berusaha dengan memanfaatkan ide dan peluang yang ada.

Berbagai hal penting ketika akan membentuk atau memdirikan suatu wirausaha maka yang harus diperhatikan adalah aspek hukum. Bisnis dan hukum tidak dapat dipisahkan seperti bisnis dengan komponen-komponen lainnya. Selain hukum mengandung pengertian aturan-aturan yang dapat diberlakukan untuk mengatur hubungan-hubungan antar manusia dan antara manusia dengan masyarakatnya, bisnis juga mengandung pengertian keseluruhan kegiatan usaha yang dijalankan oleh orang atau badan secara teratur dan terus menerus, yaitu berupa kegiatan mengadakan barangbarang atau jasa-jasa maupun fasilitas-fasilitas untuk untuk diperjualbelikan, dipertukarkan atau disewagunakan dengan tujuan mendapatkan keuntungan.

Pentingnya aspek hukum bagi suatu usaha sangatlah diperlukan, karena dengan status badan hukum merupakan dasar yang penting ketika kita mulai berwirausaha, maka dari itu perusahaan haruslah memiliki badan hukum tertentu agar dapat memiliki legalitas dalam menjalankan aktivitasnya. Keberadaan badan hukum perusahaan akan melindungi perusahaan dari segala tuntutan akibat aktivitas yang dijalankannya. Karena badan hukum perusahaan memberikan kepastian berusaha, sehingga kekhawatiran atas pelanggaran hukum dapat di antsipasi, atau terhindar mengingat badan hukum perusahaan memiliki rambu-rambu yang harus dipatuhi.

Dengan memiliki badan hukum maka perusahaan akan memenuhi kewajiban dan hak terhadap berbagai pihak yang berkaitan dengan perusahaan baik yang ada di dalam perusahaan maupun di luar perusahaan. Berdasakan uraian tersebut, maka yang menjadi permasalahan sebagai berikut bagaimana karakteristik dan aspek hukum dalam kewirausahaan.

\section{B. METODE PENELITIAN}

Jenis penelitian ini merupakan library research (penelitian kepustakaan) merupakan pengumpulan data yang diperoleh langsung dan menelaah dari berbagai referensi yang relevan dengan masalah yang diteliti. Metode pengumpulan bersumber data-data yang diperoleh dari berbagai literatur, peraturan perundang-undangan, pendapat para ahli, dokumen dengan cara mencari informasi dari laporan, koran, majalah atau perpustakaan yang memuat informasi yang sesuai dengan analisis yang dilakukan, serta tulisan lain yang terkait dengan materi yang dibahas sebagai penunjang. 
Data-data yang diperoleh dianalisis secara kualitatif kemudian disajikan secara deskriptif yaitu menguraikan, menggambarkan, dan menjelaskan sesuai dengan permasalahan yang erat kaitannya dengan obyek penelitian ini

\section{PEMBAHASAN}

Kewirausahaan Secara etimologis kewirausahaan berasal dari dua kata, yaitu "wira" dan "Usaha". Definisi dari Wira yaitu manusia yang unggul, berwatak yang agung, pahlawan, pejuang, memiliki budi yang luhur, dan juga gagah berani. Sedangkan Usaha adalah bekerja dan berbuat sesuatu. Usaha dapat juga diartikan sebagai perbuatan untuk amal, daya upaya atau kegiatan dengan mengerahkan tenaga, pikiran atau badan untuk mencapai suatu maksud. Jadi wirausaha adalah pejuang atau pahlawan yang berbuat sesuatu, atau pengertian wirausaha secara umum adalah kemampuan untuk berdiri sendiri, berdaulat, merdeka lahir bathin, sumber peningkatan kepribadian, suatu proses dimana orang mengejar peluang, merupakan sifat mental dan sifat jiwa.

Kewirausahaan sebagai suatu proses penciptaan sesuatu yang baru (kreasi baru) dan membuat sesuatu yang berbeda dari yang sudah ada (inovasi) dengan tujuan agar tercapai kesejahteraan individu dan nilai tambah bagi masyarakat.

Dalam lampiran Keputusan Menteri Koperasi dan Pembinaan Pengusaha Kecil Nomor: 961/KEP/M/XI/1995 ${ }^{1}$, dicantumkan bahwa:

1. Wirausaha adalah orang yang mempunyai semangat, sikap, perilaku, dan kemampuan kewirausahaan.

2. Kewirausahaan adalah semangat, sikap, prilaku, dan kemampuan seseorang dalam menangani usaha atau kegiatan yang mengarah pada upaya mencari, menciptakan serta menerapkan cara kerja, teknologi, dan produk baru dengan meningkatkan efisiensi dalam rangka memberikan pelayanan yang lebih baik dan atau memperoleh keuntungan yang lebih besar.

Agar kita dapat keselarasan hidup dunia dan akhirat perlu adanya motivasimotivasi dalam diri untuk membangun kita agar hidup ini lebih bermanfaat. Dalam hal ini ditekankan pada aspek membangun motivasi wirausaha ${ }^{2}$, antara lain:

1. Niat yang baik, merupakan pondasi dari amal perbuatan, sebagaimana hadis Rasulullah "Sesungguhnya amalan itu tergantung pada niatnya. Dan seseorang sesuai dengan apa yang ia niatkan".

2. Membulatkan tekad, berani melangkah dapat mewujudkan keberhasilan daripada setengah-setengah atau tidak berani bertekad dipastikan gagal.

3. Percaya pada takdir dan ridha, dalam hal ini kita berfikir posotif.

4. Belajar dari filsafat alam, berawal dari yang kecil.

5. Belajar dari pengalaman wirausaha yang sukses.

6. Berinteraksi dengan akhlak, akhlak menempati posisi puncak dalam rancangan membangun ekonomi Islam.

7. Mengikuti program pengembangan, mengikuti kegiatan sosialisasi dan advokasi kewirausahaan agar dapat menumbuhkan, meningkatkan, dan mengembangkan.

8. Kunjungan kerja, melakukan kunjungan ke sentra-sentra kegiatan ekonomi/industry yang lebih maju.

${ }^{1}$ Muhammad Anwar H.M, Pengantar Kewirausahaan Teori dan Aplikasi, h 9

${ }^{2}$ Ma'ruf Abdullah, Wirausaha Berbasis Syariah, h 3-8. 
9. Kerja sebagai ibadah, dalam hal ini bekerja dengan ikhlas karena Allah.

10. Bersyukur, merupakan konsekuensi logis dari bentuk rasa terima kasih atas nikmat-nikmatyang sudah Allah berikan selama ini kepada kita.

Rakyat Indonesia yang sebagian besar beragama Islam, tidak banyak mengetahui akan ajaran Islam tentang pekerjaan di bidang bisnis. Pernah Rasulullah Saw. Ditanya oleh para sahabat, Pekerjaan apakah yang paling baik ya Rasulullah? Rasulullah menjawab, seseorang bekerja dengan tangannya sendiri dan setiap jual beli yang bersih. (HR. Al-Bazzar). Jual beli yang bersih berarti sebagian dari kegiatan profesi bisnis. Selain itu para ulama telah sepakat mengenai kebaikan pekerjaan dagang (jual beli), sebagai perkara yang telah dipraktikkan sejak zaman Nabi hingga masa kini. ${ }^{3}$

Kitab suci Al-Qur'an sama sekali tidak mencela orang-orang yang melakukan aktivitas bisnis. Mencari rezeki dengan cara berbisnis oleh Al-Qur'an dinamakan mencari karunia ilahi atau fadhlullah, sebagaimana firman Allah SWT ${ }^{4}$ dalam Q.S. alBaqarah/2: 198

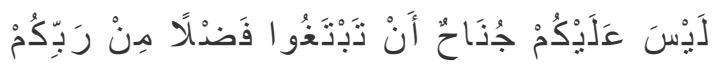

Terjemahan:

Tidak ada dosa bagimu untuk mencari karunia (rezeki hasil perniagaan) dari Tuhanmu.

Dalam ayat lain dalam Q.S. al-Jumu'ah/62:10:

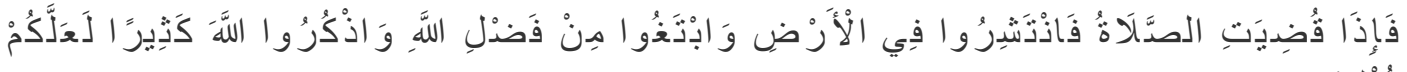

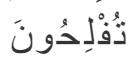

Terjemahan:

Apabila telah ditunaikan shalat, maka bertebaranlah kamu di muka bumi; dan carilah karunia Allah dan ingatlah Allah banyak-banyak supaya kamu beruntung.

Dengan demikian, berbisnis itu tidak masalah. Hanya saja, aktivitas ini harus dilakukan dengan penuh ihtiyath (kehati-hatian) supaya tidak terjerumus ke dalam kategori Maghrib, yaitu maisir, gharar, dan riba. Yang dimaksud dengan maisir ialah al-qimar (game of hazard). ${ }^{5}$ Dalam Q.S. al-Jumuah/5: 91 :

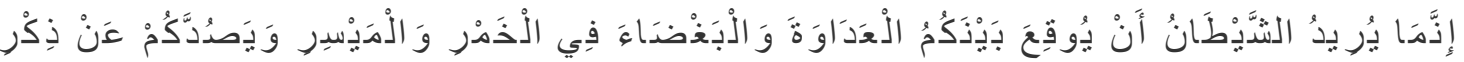

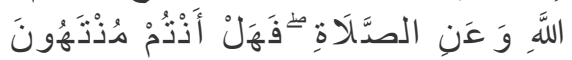

Terjemahan:

Sesungguhnya syaitan itu bermaksud hendak menimbulkan permusuhan dan kebencian di antara kamu lantaran (meminum) khamar dan berjudi itu, dan

${ }^{3}$ Prof.Dr. H. Buchari Alma, Kewirausahaan (Bandung: Alfabeta, 2007), h.3

${ }^{4}$ Drs. A. Kadir, Hukum Bisnis Syariah Dalam Al-Qur'an (Jakarta: Amzah, 2010), h. 55

${ }^{5}$ Drs. A. Kadir, Hukum Bisnis Syariah Dalam Al-Qur'an, h. 57 
menghalangi kamu dari mengingat Allah dan sembahyang; maka berhentilah kamu (dari mengerjakan pekerjaan itu).

\section{Karakteristik Kewirausahaan (Wirausaha)}

Karakteristik adalah fitur pembeda atau kualitas tertentu, ciri yang khas dari seseorang atau sesuatu. Karakteristik wirausaha dapat diartikan sebagai sesuatu yang berhubungan dengan ciri khas, watak, perilaku, tabiat, serta sikap orang terhadap perjuangan hidup untuk mencapai kebahagiaan lahir batin.

Karakteristik kewirausahaan atau wirausaha merupakan kualitas atau sifat yang terus menerus atau kekal yang dapat ditemukan pada sikap-sikap atau tindakan yang dilakukan oleh seseorang wirausaha. Sikap dan tindakan ini biasanya melingkupi sebagian besar dari sikap seorang wirausaha dalam kesehariannya dan merupakan sikap dan tindakan yang dijalankan dalam kehidupan sehari-hari. Wirausaha yang berhasil dapat dilihat dari sikap kesehariannya, antara lain mempunyai komitmen dan tidak setengah-setengah dalam melakukan suatu pekerjaan. Ia juga berani mengambil risiko yang telah diperhitungkan sebelumnya dan berani mengambil peluang sekecil apapun. Menurut M. Scarborough dan Thomas W. Zimmeree sebagaimana dikutip Suryana. Karakteristik kewirausahaan atau wirausaha antara adalah sebagai berikut:

1. Desire for Responsibility. Seorang wirausaha memiliki rasa tanggung jawab atas usaha-usaha yang dilakukannya.

2. Preference for Moderate Risk. Wirausaha lebih memilih risiko yang moderat, menghindari risiko rendah dan risiko tinggi.

3. Confidence. Wirausaha memiliki kepercayaan akan kemampuan dirinya sendiri untuk bisa berhasil.

4. Desire for immediate Feedback. Seorang wirausaha selalu menghendaki adanya umpan balik sesegera mungkin.

5. High Level of Energy. Seorang wirausaha memiliki semangat yang tinggi dan selalu bekerja keras untuk mewujudkan keinginannya demi masa depan yang lebih baik.

6. Future Orientation. Wirausaha selalu berorientasi ke masa depan, memiliki perspektif dan berwawasan jauh ke depan.

7. Skill at Organizing. Wirausaha memiliki keterampilan dalam mengorganisasikan sumber daya untuk menciptakan nilai tambah.

8. Value Achievement Over Money. Wirausaha selalu menilai prestasi dengan uang.

Banyak ahli mengemukakan karakteristik kewirausahaan dengan berbagai konsep yang berbeda-beda. Dalam Islam karakteristik wirausaha (Buchari, Alma, 2006). ${ }^{6}$

1. Sifat takwa, tawakal, zikir, dan syukur

2. Jujur

3. Bangun subuh dan bekerja

4. Toleransi

5. Berzakat dan berinfak.

${ }^{6}$ Muhammad Anwar H.M Pengantar Kewirausahaan Teori dan Aplikasi, h.19 


\section{Aspek Hukum Kewirausahaan}

Al Hukmu atau Hukm jamaknya Ahkam, yang secara harfiah mengandung arti; putusan ketetapan dan kekuasaan. Kata hukum yang sudah baku dan popular dalam khazanah bahasa Indonesia, berasal dari bahasa Arab. Pada pokoknya hukum ialah peraturan-peraturan yang bersifat memaksa, yang menentukan tingkah laku manusia dalam lingkungan masyarakat, yaitu peratutan-peraturan yang dibuat oleh badan-badan resmi yang berwajib, pelanggaran terhadap perautran-peraturan tersebut berakibat diambilnya tindakan yaitu dengan hukuman tertentu. Sesungguhnya peranan hukum dalam konteks ekonomi adalah menciptakan ekonomi dan pasar yang kompetitif ${ }^{7}$.

Berbagai pihak yang terlibat dalam kegiatan kewirausahaan akan berpijak pada setiap ketentuan yang telah disepakati bersama dan sah secara hukum. Sehingga tidak akan ada yang dengan gampang menyimpang dari peraturan jika sebelumnya telah ditetapkan aspek hukum dalam dunia wirausaha yang sedang ditekuni. Dan akan mudah menentukan kebijakan selanjutnya ketika terdapat jejak rekam jika sesuatu terjadi perselisihan antara beberapa pihak yang berkaitan dan tiap persoalan dapat diselesaikan dengan baik dan dengan seadil-adilnya.

Bisnis (wirausaha) yang dilakukan lazimnya bisa dilakukan oleh perseorangan dan bisa juga dengan suatu perkumpulan, dalam arti perkumpulan yang berbentuk badan hukum.

Untuk mendirikan suatu badan hukum, mutlak diperlukan pengesahan dari pemerintah, misalnya dalam hal mendirikan PT (Perseroan Terbatas), mutlak diperlukan pengesahan akta pendirian dan anggaran dasarnya oleh pemerintah (Menteri Hukum dan Ham cq. Direktorat Perdata). Sebuah usaha akan dikatakan telah berbadan hukum jika telah memiliki minimal \& quot;Akte pendirian \& quot; yang disahkan oleh Notaris. (Ditandatangani dengan materai dan segel). Ditambah lagi dengan adanya SIUP (Surat Izin Mendirikan Usaha) dan SK menteri Kehakiman yang diterima dalam pengesahan akte pendirian. Mereka yang telah berbadan hukum sebenarnya memiliki manfaat yaitu dengan berbadan hukum usahanya terdaftar pada Kementerian Perindustrian, Kementerian Perdagangan, pemerintah daerah dan instansi terkait lainnya. Dengan usaha yang sudah terdaftar tersebut, instansi terkait dan pemerintah daerah bisa melibatkan mereka dalam berbagai aktivitas baik dalam negeri maupun luar negeri, yang secara tidak langsung bisa memperkenalkan usaha serta membantu pemasaran sekaligus perluasan pasar.

Analisis hukum yang merupakan tujuan dari aspek hukum dalam suatu kegiatan bisnis adalah untuk meneliti keabsahan, kesempurnaan, dan keaslian dari dokumendokumen yang dimiliki oleh suatu perusahaan. Badan usaha yang akan menjalankan bisnis perlu mempersiapkan hal hal yang berkaitan dengan aspek hukum seperti badan hukum perusahaan yang dipilih seperti Perseroan Terbatas (PT), Firma , Koperasi dan Yayasan.

Dokumen -dokumen yang akan diteliti tergantung dari jenis usaha dan yang terpenting adalah urutan prioritas yang menunjukan bahwa dokumen tersebut sangat penting bagi usaha yang akan di ajukan nanti. Masalah - masalah yang akan yang akan diteliti secara umum sehubungan dengan aspek hukum ini, sebagai berikut:

1. Bentuk Badan Usaha

${ }^{7}$ Drs. A. Kadir, Hukum bisnis syariah dalam Al Qur'an, h 16-17 
Badan usaha adalah payung hukum yang membawahi usaha yang akan dijalankan, dimana payung hukum ini penting agar perusahaan tidak melanggar hukum dalam menjalankan aktivitasnya, artinya di mata hukum, perusahaan yang dijalankan sah, dan jika suatu hari terdapat tuntutan hukum maka usaha tersebut dapat dilindungi.

Jenis-jenis bentuk badan hukum yang lazim di Indonesia, sebagai berikut: (Arif Yusuf Hamali, 2016:232)

1). Perseroan Terbatas (PT), yang disebut juga Naamloze Vennotschap (NV).

Badan Hukum yang didirikan berdasarkan perjanjian dan tanggung jawab terbatas. Terbatas artinya terbatas tanggungjawabnya hanya sebatas modal yang disetorkan.

2.) Perseroan Komanditer (Commanditaire Vennotschap atau CV).

suatu persekutuan yang didirikan oleh seorang atau beberapa orang yang mempercayakan uang atau barang kepada seorang atau berapa orang yang menjalankan perusahaan dan bertindak sebagai pemimpin. Persekutuan komanditer biasanya didirikan dengan Akta dan harus didaftarkan.

3). Firma

Firma (dari bahasa Belanda vennotschap onder firma; secara harfiah: perserikatan dagang antara beberapa perusahaan) atu sering juga disebut $\mathrm{Fa}$, adalah sebuah bentuk persekutuan untuk menjalankan usaha antara dua orang atau lebih dengan memakai nama bersama. Pemilik firma terdiri dari beberapa orang yang bersekutu dan masing-masing anggota persekutuan menyerahkan kekayaan pribadi sesuai yang tercantum dalam Akta Pendirian perusahaan.

\section{4). Koperasi}

Koperasi merupakan badan usaha yang beranggotakan beberapa orang, artinya koperasi merupakan kumpulan orang yang secara bersama-sama melakukan usaha. Badan hukum koperasi melandaskan kegiatannya berdasarkan prinsip koperasi yang dianggap sebagai gerakan ekonomi rakyat berdasarkan asas kekeluargaan. Koperasi dibentuk melalui rapat anggota minimal dua puluh orang yng masing -masing memenuhi tiga yakni mampu melaksanakan tindakan hukum, menerima landasan idiil, asas dan sendi dasar koperasi; dan sanggup dan bersedia melakukan kewajiban dan hak sebagai anggota koperasi.

5). Yayasan

Yayasan (Inggris: foundation) adalah adalah suatu badan hukum yang mempunyai maksud dan tujuan sosial, keagamaan dan kemanusiaan, didirikan dengan memperhatkan persyaratan formal . Prosedur pendirian yayasan dilakukan dengan Akta Notaris dan mempunyai status badan hukum.

2. Bukti Diri

Bukti diri ini berupa kartu identitas para pemilik usaha yang dikeluarkan oleh kelurahan setempat dalam bentuk Kartu Tanda Penduduk (KTP).

3. Tanda Daftar Perusahaan (TDP)

Pengurusan surat TDP yang dikeluarkan oleh Departemen Perindustrian dan Perdagangan biasanya pada saat perusahaan mengurus akta pendirian perusahaan tersebut.

4. Nomor Pokok Wajib Pajak (NPWP)

Pengurusan NPWP juga dilakukan bersamaan dengan pengajuan akta notaris ke Departemen Kehakiman. NPWP sangat penting agar setiap usaha yang dilakukan nantinya akan memberikan penghasilan kepada pemerintah.

5. Izin-izin Perusahaan

Penelitian keabsahan dokumen izin-izin ini juga hendaknya dijalankan ke departemen teknis. Izin-izin tersebut antara lain:

1) Surat Izin Usaha Perdagangan (SIUP), bagi perusahaan yang bergerak dalam bidang usaha perdagangan dari deperindag.

2) Surat Izin Usaha Industri (SIUI); bagi perusahaan atau usaha yang bergerak dalam bidang usaha industri dari Deperindag. 
3) Izin Usaha Tambang dari Departemen Pertambangan.

4) Izin Usaha Perhotelan dari Pariwisata dari Departemen Pariwisata.

5) Izin Usaha Farmasi dan Rumah Sakit dari Departemen Kesehatan.

6) Izin Usaha Peternakan dan Pertanian dari Departemen Pertanian.

7) Izin Domosili, dimana perusahaan/lokasi proyek berada di pemerintah

8) Izin gangguan untuk usaha tertentu guna menghindari segala kemungkinan hal-hal yang tidak diinginkan.

9) Izin Mendirikan Bangunan (IMB), khusus untuk pendirian gedung baru atau merehab pembangunan suatu gedung.

10) Izin tenaga kerja asing jika ada.

6. Keabsahan Dokumen lainnya, yaitu berupa status hukum tanah dan kendaraan bermotor.

Keaslian surat-surat kendaraan yang akan digunakan untuk usaha tersebut seperti usaha jasa angkutan yaitu: Bukti Pemilikan Kendaraan Bermotor(BPKB, harga beli (faktur dan kuitansi), kondisi kendaraan, dan izin trayek (jika usaha transportasi).

\section{KESIMPULAN}

\section{Kesimpulan}

1. Wirausaha dalam pandangan Islam, bekerja dan berusaha, bagian tak terpisahkan dari kehidupan manusia karena keberadaannya sebagai pengelola (khalifah fil-ardh) kemakmuran bumi dan membawanya ke arah yang lebih baik.

2. Pentingnya berbadan hukum bagi suatu usaha sangatlah diperlukan, melindungi perusahaan dari segala tuntutan akibat aktivitas yang dijalankannya. perusahaan akan memenuhi kewajiban dan hak terhadap berbagai pihak yang berkaitan dengan Saran perusahaan baik yang ada di dalam perusahaan maupun di luar perusahaan.

Aspek hukum dalam setiap kegiatan kewirausahaan sangat di anjurkan bagi setiap pelaku usaha atau kelompok usaha tertentu untuk dapat menyadari manfaat serta mengaplikasikannya dalam setiap kegiatan wirausaha, baik dalam skala kecil maupun dalam skala besar. Sehingga sebelum kegiatan wirausaha itu dijalankan, maka perlu prosedur yang berkaitan dengan izin-izin atau berbagai persyaratan harus terlebih dahulu sudah terpenuhi

\section{DAFTAR PUSTAKA}

Alma, Buchari. Kewirausahaan. Bandung: Alfabeta, 2009.

------. Pengantar Bisnis. Bandung: Alfabeta, 2012.

Anwar, Muhammad. Pengantar Kewirausahaan. Jakarta: Prenada, 2014.

Hamali, Ali Yusuf. Pemahaman Strategi Bisnis dan Kewirausahaan. Jakarta: Prenadamedia Group, 2016.

Juhanis. Manajemen Kewirausahaan Islam. Makassar: Alauddin University Press.2014.

Jati, Bambang Murdaka Eka dan Priyambodo Tri Kuntoro. Kewiausahaan. Yogyakarta: Andi, 2015.

Kadir, A. Hukum Bisnis Syariah Dalam AlQuran. Jakarta: Amzah, 2010.

Simatupang, Richard Burton. Aspek Hukum Dalam Bisnis. Jakarta: Rineka Cipta, 2007. 